\title{
DISTANCE LEARNING WITH STEAM APPROACHES: IS THE EFFECT ON THE COGNITIVE DOMAIN?
}

\author{
Aminah Zb \\ State Islamic Universty Sulthan Thaha Saifuddin Jambi, Jambi, Indonesia \\ E-mail:aminabzb@uinjambi.ac.id \\ Devie Novalian \\ State Islamic Universty Sulthan Thaha Saifuddin Jambi, Jambi, Indonesia \\ E-mail:devienovalian@uinjambi.ac.id
}

Rizki Ananda

Universitas Pablawan Tuanku Tambusai, Riau, Indonesia E-mail : rizkiananda@universitaspablawan.ac.id

\section{Mhmd Habibi}

State Islamic Universty Sultan Syarif Kasim, Riau, Indonesia E-mail:mhmd_habibi@yahoo.com

\section{Fauzan Sulman*}

State Islamic Universty Sulthan Thaha Saifuddin Jambi, Jambi, Indonesia E-mail:fauzansulman@uinjambi.ac.id

\section{(c) (1) (2)}

(C)2021 by the authors. Submitted for possible open access publication under the terms and conditions of the Creative Commons Attribution (CC-BY-SA) license (https://creativecommons.org/licenses/by-sa/4.0/) doi $D O I:$ http://dx.doi.org/10.30983/educative.v6i2.4977

*Corresponding author

\begin{tabular}{|l|l|l|} 
Submission: November 08, 2021 & Revised: December 12, 2021 & Published : December 31, 2021 \\
\hline
\end{tabular}

\section{Abstract}

This study uses a STEAM approach to learning outcomes of biological innovation, using a quantitative approach with a quasi-experimental method with a posttest-only design with a nonequivalent group design. The population in this study are fourth-semester students of Biology Tadris UIN Sulthan Thaha Saifuddin Jambi, class IVA, IVB, IVC, and VI D, totaling 36 people. Samples were taken using class IVA and IV D with the purposive sampling technique. The instrument in this study was in the form of five essay test questions. Data analysis used t-test and correlation test (phi $(\Phi)$ ). Analysis of t-test data from the calculation results shows that the use of the STEAM approach is proven to be better than online lectures without using the STEAM approach. The results of the study were continued with a correlation test (phi test $(\Phi)$ ), from the results of the calculations, it was concluded that the STEAM approach had a significant effect on the learning outcomes of students' cognitive domains in the biology learning innovation course.

Keywords: Cognitive Domain, Distance Learning, Learning Outcome, STEAM Approach

\section{Abstrak}

Penelitian ini menggunakan pendekatan STEAM terhadap hasil belajar inovasi biologi, menggunakan pendekatan kuantitatif dengan metode kuasi eksperimen dengan desain posttest only dengan nonequivalent group design. Populasi dalam penelitian ini adalah mahasiswa semester IV Biologi Tadris UIN Sulthan Thaha Saifuddin Jambi kelas IVA, IVB, IVC, dan VI D yang berjumlah 36 orang. Sampel yang digunakan adalah kelas VIA dan IV D diambil dengan menggunakan teknik purposive sampling. Instrumen dalam penelitian ini berupa 5 soal tes essay. Analisis data menggunakan uji-t dan uji korelasi (phi $(\Phi))$. Analisis data üi t Dari hasil perbitungan diperoleh kesimpulan bahwa penggunaan pendekatan STEAM terbukti lebih baik daripada perkuliababan online tanpa menggunakan pendekatan STEAM. Hasil penelitian dilanjutkan dengan uji korelasi (uji phi (Ф)), dari hasil perbitungan diperoleh kesimpulan babwa pendekatan STEAM berpengaruh signifikean terhadap hasil belajar ranah kognitif mahasiswa pada mata kuliah inovasi pembelajaran biologi.

Kata Kunci: Hasil Belajar, Ranah Kognitif, Perkuliahan Jarah Jauh, Pendekatan STEAM 


\section{Introduction}

In the Industrial Era 4.0, teaching paradigms require students to be creative in innovating as well as to think systematically and integrate knowledge. Science's rapid advancement has resulted in dramatic changes in all aspects of life, including education ${ }^{1}$. With technological advancements, information should be a catalyst for both educators and students to activate thinking skills capable of competing with the demands of the times. In the Industrial Revolution 4.0, the process of passing on knowledge from one person to another is deemed insufficient. However, there must be knowledge innovation with high creativity because new discoveries can lead to a more effective and quality understanding ${ }^{2}$.

The lecture process should run optimally in all conditions ${ }^{34}$, whether under

1 Seher Ozkazanc and Ulku Duman Yuksel, 'Evaluation of Disaster Awareness and Sensitivity Level of Higher Education Students', Procedia - Social and Behavioral Sciences, 197.February (2015), 745-53 <https://doi.org/10.1016/j.sbspro.2015.07.168>; Pengyue Guo and others, 'A Review of Project-Based Learning in Higher Education: Student Outcomes and Measures', International Journal of Educational Research, 102.November $2019 \quad$ (2020), 101586 <https://doi.org/10.1016/j.ijer.2020.101586>.

2 Nemanja Sremcev and others, 'Improving Teaching and Learning Process by Applying Lean Thinking', Procedia Manufacturing, 17 (2018), 595-602 <https://doi.org/10.1016/j.promfg.2018.10.101>;

Ilona Kuzmickaja and others, 'In Need of Creative Mobile Service Ideas? Forget Adults and Ask Young Children', SAGE Open, $5.3 \quad$ (2015) <https://doi.org/10.1177/2158244015601719>.

${ }^{3}$ Edi Rozal and others, 'The Effect of ProjectBased Learning through YouTube Presentations on English Learning Outcomes in Physics', AL-ISHLAH: Jurnal Pendidikan, 13.3 (2021), 1924-33 <https://doi.org/10.35445/alishlah.v13i3.1241>; M Ikhbal Jaya Putra, M Junaid, and Fauzan Sulman, 'The Ability of the Question and Answer (Q\&A) Method with the Help of Learning Videos against Student Learning Outcomes amid the Covid-19 Pandemic', EDUKATIF: Jurnal Ilmu Pendidikan, 3.5 (2021), 2160-69 <https://doi.org/https://doi.org/10.31004/edukatif.v 3i5.768>.

${ }^{4}$ Fauzan Sulman, Sutop Sutopo, and Sentot Kusairi, 'FMCE-PHQ-9 Assessment with Rasch Model in Detecting Concept Understanding, Cheating, and Depression amid the Covid-19 Pandemic', Tadris: Jurnal normal or abnormal circumstances and this is a challenge for an educator in this case lecturers who teach at universities to be able to make a real contribution in increasing student motivation and learning outcomes ${ }^{5}$. Changes in the conditions of learning, such as different lecture methods, during the COVID-19 pandemic should not be a significant obstacle in today's education system. Technological progress should become a solution in the form of the development of lecture media; it is just a matter of how educators look for the right approach to use in the lecture process. The STEAM approach is one approach to integrate comprehensive knowledge in the modern era. The STEAM approach gives educators more flexibility to explore and also to better adapt to the new knowledge needed today and in the future.

STEAM is an educational approach that can facilitate and integrate more comprehensive knowledge, so that the knowledge gained is not just a random piece of information ${ }^{6}$. Using STEAM also allows

Keguruan Dan Ilmu Tarbiyah, 6.2 (2021), 297-309

<https://doi.org/10.24042/tadris.v6i2.9273>.

5 Aminah Zb, M Eval Setiawan, and Fauzan Sulman, 'Pengaruh E-Learning Berbasis Schoology Berbantuan WhatsApp Group Terhadap Hasil Belajar Ditengah Pandemi Covid-19', Al-Khidmah, 3.2 (2020), 55-60 <https://doi.org/10.29406/alkhidmah.v3i2.2282>; Fauzan Sulman, Tanti; Tanti, and others, 'Pengaruh Media Animasi Berkarakter Islami Terhadap Hasil Belajar Pengetahuan Bumi Dan Antariksa', Edumaspul: Jurnal Pendidikan, 5.1 (2021), 13546 <https://doi.org/10.33487/edumaspul.v5i1.1044>. 6 Armida de la Garza, 'Internationalizing the Curriculum for STEAM (STEM + Arts and Humanities): From Intercultural Competence to Cultural Humility', Journal of Studies in International Education, $25.2 \quad$ (2021), $123-35$ <https://doi.org/10.1177/1028315319888468>;

Joseph Roche and others, 'Science Communication Through STEAM: Professional Development and Flipped Classrooms in the Digital Age', Science Communication, 2021

<https://doi.org/10.1177/10755470211038506>

Rebecca J. Trueman, 'Productive Failure in Stem Education', Journal of Educational Technology Systems, 42.3 (2014), 199-214 <https://doi.org/10.2190/et.42.3.b>; $\mathrm{S}$ Tatus and others, 'Stem I Ntegration in K-12 E Ducation', March, 2014. 
students to make a creation in a high art form, ensuring that the innovations provided are exciting and can increase their interest in the learning process. ${ }^{7}$ Creativity in the form of art is an embodiment of students' innovation to express themselves in order for the knowledge provided to be both practical and enjoyable.

STEAM will encourage mastery and high level creativity ${ }^{\mathbf{8}}$. Students' interest in learning more about the lecture material grows as they gain understanding through the STEAM approach. In dealing with more rapid developments, the recovery process using the STEAM approach may be the best companion", so one must produce innovation that can lead to more excellent knowledge. This is leads to a new change in the lecture process ${ }^{10}$. The lecture process in the industrial era 4.0 requires complex abilities: a lecture material can be explained through how much knowledge is required in making a conclusion or the results of an analysis of the material being studied. Because the STEAM approach is highly integrated with some areas of knowledge, the innovation process carried out

7 Marja G. Bertrand and Immaculate K. Namukasa, 'STEAM Education: Student Learning and Transferable Skills', Journal of Research in Innovative Teaching \& Learning, $13.1 \quad$ (2020), 43-56 <https://doi.org/10.1108/jrit-01-2020-0003>; de la Garza.

${ }^{8}$ Wu Chen, Xin Tang, and Ting Mou, 'Course Design and Teaching Practice in STEAM Education at Distance via an Interactive E-Learning Platform', Asian Association of Open Universities Journal, 14.2 (2019), 122-33 <https://doi.org/10.1108/aaouj-07-2019-0027>;

Roche and others.

9 Jo Trowsdale, Ursula McKenna, and Leslie J. Francis, 'Teacher Evaluation of the Impact of The Imagineerium Education Project on the Creativity of Individual Students: The Trowsdale Index of Teacher Observation of Student Creativity', Research in Education, 2021 <https://doi.org/10.1177/00345237211014559>; Roche and others; Bertrand and Namukasa.

${ }_{10}$ Wander M van Baalen, Tamara de Groot, and Liesbeth Noordegraaf-Eelens, 'Higher Education, the Arts, and Transdisciplinarity: A Systematic Review of the Literature', Research in Education, 2021, 003452372110057

<https://doi.org/10.1177/00345237211005799>;

Trowsdale, McKenna, and Francis; de la Garza. can be a solution in dealing with the development of science in the modern era and in the future. ${ }^{11}$

The lecture process during the Covid19 pandemic required lectures to be conducted remotely. Thus, a process that could maintain creativity and innovation during lectures was required ${ }^{12}$. Teaching biology as a learning innovation should become a driving force in producing high-creativity innovation for prospective teachers, but it has been overlooked thus far. Analysis of lecture problems discovered in the field, both in theory and in practice, identifies the need for specialized treatment that interacts with one another to overcome problems that may arise during a pandemic ${ }^{13}$. The lecture process must be a source of innovation with art or creativity to develop newer and optimal knowledge by using the STEAM approach, which has not been widely practiced. The STEAM approach will be a suitable catalyst in integrating knowledge to make it more comprehensive. The STEAM Excellence factor allows researchers to improve students' cognitive understanding, especially in the biology education innovation course. The process of implementing the STEAM approach in biology learning, whether in the midst of a pandemic or not, should have been applied. The learning process must be able to contribute properly and appropriately according to the needs of an era development so that the inhibiting factors

${ }^{11}$ Fauzan Sulman, 'Application of Cooperative Problem Posing and Prior Motivation Towards Students Learning Outcomes', Indonesian Journal of Educational Research (IJER), 4.2 (2019), 93-96 $<$ https://doi.org/10.30631/ijer.v4i2.126>; Bertrand and Namukasa.

12 Fauzan Sulman, Muhammad Reyza Arif Taqwa, and others, 'The Effect of Mathematical Connections on the Mastery of Probability Material', Edumatika: Jurnal Riset Pendidikan Matematika, 3.2 (2020), $147-57$

<https://doi.org/10.32939/ejrpm.v3i2.645>; Z Z, Setiawan, and Sulman; Sulman, Tanti, and others.

${ }^{13}$ Putra, Junaid, and Sulman; Zb, Setiawan, and Sulman. 
occuring in the process of integrating various knowledge in one unified frame can be overcome by applying the STEAM approach appropriately.

\section{Method}

This research uses a posttest-only group with a nonequivalent group design. The design of the study can be seen in Figure 1.

Figure 1. The Posttest Only Design With Nonequivalent Group

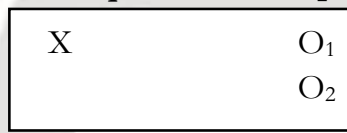

Source: Creswell, 2012

The research design above shows that the experimental class $\left(\mathrm{O}_{1}\right)$ had a STEAM approach in this study, while the control class $\left(\mathrm{O}_{2}\right)$ was without a STEAM approach. The population in this study was fourth-semester students in 2020/2021 with four classes at UIN Sulthan Thaha Saifuddin Jambi, with as many as 36 students. The sample used a purposive sampling technique. Two classes were selected, consisting of Class IVA as the Experiment class, totaling ten people, Class IVD as the control class with eight students. The instrument used in the assessment of the final test (posttest) is a description test with a total of five questions, which were previously carried out with logical validity by two lecturers. Suggestions and criticisms given by experts on test instruments become a reference and input for researchers in making good and quality test questions. The process of repairing the completed test instrument is shown back to the expert and re-analyzed until the instrument is decided by the expert to be suitable for use without requiring further revision ${ }^{14}$.

The research results test was preceded by a prerequisite test using the $\mathrm{X}^{2}$ chi-square test with normal results and the $\mathrm{F}$ test with the

\footnotetext{
${ }_{14}$ Putra, Junaid, and Sulman; Zb, Setiawan, and Sulman; Sulman, Tanti, and others.
}

results obtained by homogeneous samples ${ }^{15}$. The facts obtained from the prerequisite test indicate choosing the right statistics to carry out measurements in this study, Because the population is normal and the sample is homogeneous, the decision was taken to perform a t-test and phi correlation to see the differences and the significance of the effect of the STEAM approach on learning outcomes in the cognitive domain in biology learning innovation course. The use of this statistic is very appropriate to be used in this study because it is in accordance with the aim of the researcher in this study, namely to see how the influence of distance learning using the STEAM approach, especially the influence on the cognitive domain in lectures during the Covid-19 pandemic and how significant the STEAM approach is in influencing learning outcomes in the cognitive domain in distance learning.

\section{Result and Discussion \\ Result}

Facts obtained from the study, where researchers examined how a STEAM approach influenced learning outcomes in the cognitive domain, were taken from the answers to five final test questions. The data analysis of student learning outcomes during a pandemic in the biology learning innovation course, specifically in the cognitive domain, can be seen in table 1 :

${ }^{15}$ Rozal and others; Aminah Zb, Devie Novalian, and others, 'STEM Approach in Online Lectures: How Does It Contribute to Cognitive Aspects?', Indonesian Journal of Science and Education, 5.2 (2021), 88-97 <https://doi.org/10.31002/ijose.v5i2.4365>; Aminah Zb, M. Eval Setiawan, and others, 'Investigating Hybrid Learning Strategies: Does It Affect Creativity?', Jurnal Kependidikan: Jurnal Hasil Penelitian Dan Kajian Kepustakaan Di Bidang Pendidikan, Pengajaran Dan Pembelajaran, $\quad 7.4 \quad$ (2021), $868-75$ <https://doi.org/10.33394/jk.v7i4.4063>. 
Table 1. Posttest Value of Learning Outcomes

\begin{tabular}{clcc}
\hline \multirow{2}{*}{ No Parameter } & $\begin{array}{c}\text { Experiment } \\
\text { Class }\end{array}$ & $\begin{array}{c}\text { Control } \\
\text { Class }\end{array}$ \\
\hline $\begin{array}{c}\text { Posttest } \\
1\end{array}$ & Number of students & 10 & 8 \\
\hline 2 & Lowest Score & 85 & 65 \\
\hline 3 & highest score & 95 & 75 \\
\hline 4 & Average score & 90,25 & 74,25 \\
\hline
\end{tabular}

Based on the facts obtained where students' scores in the experimental class are much better than the control class, both in terms of average scores, the lowest scores, and the highest scores, students using the STEAM approach have much better learning outcomes in the cognitive domain. The research process was continued by conducting prerequisite tests for the accuracy of the instrument decided in the study, namely homogeneity and normality tests. The analysis of the normality test in the experimental class, which amounted to 10 people with a value of $\alpha=0,05$ or $5 \%$, obtained the results of $\mathrm{X}_{\text {count }}^{2} \leq \mathrm{X}_{\text {table, }}^{2}, 0,221 \leq$ 0,258 . It was concluded that the experimental class was normally distributed. In comparison, in the control class, the number of students was eight people with $\alpha=0,05$ or $5 \%$ results obtained $X^{2}$ count $\leq X_{\text {table }}^{2}, 0,320 \leq 0,331$ in other words, the data is usually distributed. In the analysis of the normality test using the $\mathrm{F}$ test where $\mathrm{X}_{\text {tabel }}^{2}$ is obtained at 4,545 and $\mathrm{X}_{\text {count }}^{2}=1,45$. So it can be concluded that $\mathrm{X}_{\text {count }}^{2} \leq \mathrm{X}_{\text {table. Thus, the data variants are }}^{2}$ homogeneous, which becomes the basis for determining the research analysis followed by a t-test to see differences in learning outcomes in the experimental and control class. The results between the experimental and control classes both from the calculation results and from the results of the analysis from the table can be seen comprehensively in table 2 .
Table 2. t-test the difference in learning

\begin{tabular}{|c|c|c|c|c|}
\hline \multirow{2}{*}{$\begin{array}{c}\mathrm{Nu} \\
\mathrm{mbe} \\
\mathbf{r}\end{array}$} & \multicolumn{2}{|c|}{$\begin{array}{c}\text {-Test } \\
\text { Value }\end{array}$} & \multirow{2}{*}{$\begin{array}{c}\text { Compariso } \\
\text { n of } t \text {-test } \\
\text { Values } \\
-\boldsymbol{t}_{\text {table }} \leq \\
\boldsymbol{t}_{\text {count }} \\
\leq+\boldsymbol{t}_{\text {table }}\end{array}$} & \multirow[b]{2}{*}{ Conclusion } \\
\hline & $\begin{array}{c}t_{\text {coun }} \\
t\end{array}$ & $t_{t a b l e}$ & & \\
\hline 1. & 2,37 & $\begin{array}{c}1,74 \\
6\end{array}$ & $\begin{array}{c}1,7746 \leq \\
2,37 \geq+ \\
1,746\end{array}$ & $\begin{array}{c}\mathrm{H}_{\mathrm{o}} \text { is rejected } \\
\text { and } \mathrm{H}_{\mathrm{a}} \text { is } \\
\text { accepted }\end{array}$ \\
\hline
\end{tabular}

Based on the results of the analysis of student data, which amounted to 18 people, the table value at a significant level of $\alpha=5 \%$ and $d k=16$ was 1.746 , which was different from the ${ }^{\mathrm{t}}$ count value of 2.37. Thus $\mathrm{Ha}$ is accepted, and $\mathrm{Ho}$ is rejected, which means there is a class difference in treatment in the experimental class compared to the control class. After the difference analysis process obtained data, the analysis process continued by looking at the significance of the effect of a treatment in the form of a STEAM approach in biology learning innovation lectures on learning outcomes in the cognitive domain of students using the phi correlation test technique. The facts found based on the results of the analysis that have been carried out are compared with the table values so that a conclusion can be drawn, which can be seen in the values in Table 3.

Table 3. Correlation test (phi Test Value ( $\Phi)$ )

\begin{tabular}{|c|c|c|c|c|}
\hline \multirow[t]{2}{*}{ No } & \multicolumn{2}{|c|}{$\begin{array}{c}\text { phi test } \\
\text { value }(\Phi)\end{array}$} & \multirow{2}{*}{$\begin{array}{l}\text { Comparison } \\
r_{\text {table }} \leq r_{\text {count }}\end{array}$} & \multirow[t]{2}{*}{ Conclusion } \\
\hline & $r_{\text {count }}$ & $r_{\text {table }}$ & & \\
\hline 1. & 0,572 & 0,443 & $0,443 \leq 0,573$ & $\begin{array}{l}\mathrm{H}_{\mathrm{o}} \text { is } \\
\text { rejected and } \\
\mathrm{H}_{\mathrm{a}} \text { is } \\
\text { accepted }\end{array}$ \\
\hline
\end{tabular}

Analysis through the phi correlation test obtained the $r_{\text {count }}$ value of 0,573 while the value in the table where rtable at a significance level of $\alpha=5 \%$ was 0,443 . Then $r_{\text {table }} \leq r_{\text {count }}$ that is with a comparison value of $0,443 \leq$ 0,573 . This correlation test data analysis shows that the STEAM approach can significantly 
influence student cognitive learning outcomes, especially in biology learning innovation courses. What we has shown above is a very valuable finding in the learning process in lectures, especially biology education, since it demonstrates the significant influence of a STEAM approach on learning outcomes in the cognitive domain. This leads to the undeniable fact that the STEAM approach is capable and persistent in improving learning outcomes both in pandemic and normal conditions.

The significant increase in learning outcomes, which is the effects of the STEAM approach, can be the basis for educators to make the STEAM approach an appropriate alternative in the lecture process in the Industrial Era 4.0. The ability of the STEAM approach to improve learning outcomes better than the control class must of course be accompanied by the good ability of educators in carrying out the STEAM lecture process, especially in increasing the creativity of biology education students so that they can be more motivated acquire the ability to analyze and understand the material more comprehensively and have high creativity from the results of the lecture process that has been carried out.

\section{Discussion}

This research that has been carried out aims at providing educational solutions that can be used in the online lecture process ${ }^{16}$. The research process that has been carried out shows the ability of STEAM in improving student learning outcomes. These are seen in more detail in terms of the differences that occur compared to the control class and the real significance of the influence of a STEAM approach on learning outcomes, especially in the cognitive domain. The lecture process amid a pandemic requires a change in learning patterns from offline to online ${ }^{17}$. This requires

${ }^{16} \mathrm{Zb}$, Setiawan, and Sulman.

${ }^{17}$ Sulman, Tanti, and others. educators to find solutions. The implementation of online lectures is a substitute for media in the lecture process and can support and continue to maximize student learning outcomes ${ }^{18}$. To increase understanding in online lectures, students must constantly innovate in the form of creativity ${ }^{19}$ with high art so that they can be enjoyed by students in the biology education lecture process ${ }^{20}$. Education in the Industrial Era 4.0 prioritizes individual adaptability in order to avoid lagging behind the very rapid changes of the times, especially in the field of technology. The development of the times in the field of technology is certainly not something that can be ignored, but must be utilized as much as possible ${ }^{21}$. In utilizing the resources of the times, especially in the field of technology, especially by educators, the purpose of the lecture process must be directed not only to learning outcomes in the cognitive domain but rather to facilitating students in increasing creativity, so that they are not left behind with the changing times.

Lectures during the pandemic that are conducted online require clear implementation; the process in online lectures requires a good and clear structure so that the knowledge to be conveyed can also be conveyed adequately. Thus the STEAM approach is the right solution to carry out in the learning process and in the implementation process. This requires good skill and ability on the part of the educator to

${ }^{18} \mathrm{Zb}$, Novalian, and others.

19 David Hayes, 'Against Critical Thinking Pedagogy', Arts and Humanities in Higher Education, 14.4 (2015), 318-28 <https://doi.org/10.1177/1474022215592248>; Tuan Mastura Tuan Soh, Nurazidawati Mohamad Arsada, and Kamisah Osman, 'The Relationship of 21st Century Skills on Students' Attitude and Perception towards Physics', Procedia - Social and Behavioral Sciences, 7.C (2010), $546-54$ <https://doi.org/10.1016/j.sbspro.2010.10.073>.

20 van Baalen, de Groot, and NoordegraafEelens; Trowsdale, McKenna, and Francis. ${ }^{21}$ Sulman. 
apply it in thelearning process ${ }^{22}$. In the lecture process, the student's ability must be maintained consistently, so that all treatments carried out in improving learning outcomes can be fulfilled properly ${ }^{23}$. In other words students' abilities during online lectures must always be optimized, especially abilities that can be integrated with comprehensive and necessary knowledge of several interrelated fields ${ }^{24}$.

The innovation process in the STEAM approach and art in work will be the most appropriate tool in overcoming boredom during the online lecture process ${ }^{25}$. Teachers to instill confidence in building new knowledge or modifying old knowledge more effectively and efficiently to build a quality system, especially for the online lecture process applied to biology education subjects. The innovation process will make students able to create a series of education initiatives that are genuinely interrelated in a manner that remains relevant in the changing times ${ }^{26}$

\section{STEAM Approach in Influencing Student Cognitive Learning Outcomes}

Research conducted using a scientific approach shows several important facts about the contribution of the STEAM approach in influencing student learning outcomes specified in the cognitive domain in terms of the differences between the experimental class and the control class. It can also be observed how the effect of the STEAM approach on student learning outcomes is primarily on the Mou.

22 Bertrand and Namukasa; Chen, Tang, and

23 Meiliani Meiliani, Tanti Tanti, and Fauzan Sulman, 'STUDENT RESOURCE ON NEWTON' S LAW CONCEPTS REVIEWING FROM GENDER : IDENTIFICATION USING OPEN-ENDED QUESTIONS', Indonesia Journal of Science and Mathematics Education, 04.November (2021), 324-32 <https://doi.org/10.24042/ijsme.v4i3.10177>.

${ }^{24}$ Bertrand and Namukasa; de la Garza.

${ }^{25}$ van Baalen, de Groot, and Noordegraaf-Eelens; Putra, Junaid, and Sulman.

${ }^{26}$ Sulman; Sulman, Tanti, and others. cognitive domain. The results of the data analysis that have been carried out show that there are differences, and it is clear that this cannot be separated from the treatment given where the experimental class is given a STEM approach in the lecture process. In contrast, the control class is not given special treatment. The analysis of several research that have been carried out shows that the difference is due to the difference in treatment given ${ }^{27}$, where the experimental class in the implementation of lectures is focused on how students can be innovative in lectures. This occurs by asking students to make a research proposals that can overcome the problems of biology education, in other words, directly dealing with the reality that occurs in the field ${ }^{28}$. This way, students can trigger creativity in learning that can be more effectively and efficiently used in several conditions, both normal and extraordinary conditions. Lectures using the STEAM approach can be the best solution in conducting online lectures to maintain maximum quality and learning outcomes.

The STEAM approach applied to the experimental class provides a significant difference: the experimental class with the STEAM approach is better than the class without the STEAM approach. If examined further, this is because the lecture process in the control class is more similar to conventional learning, so students are not led to be more creative in the lecture process. Online lectures conducted in the control class without the STEAM approach should direct students' to be more independent in carrying out the lecture process. However, in reality, this has not been done optimally, so students are less interested and willing to explore or innovate in building solutions to a problem in a manner that can provide confidence to

\footnotetext{
${ }^{27}$ Sulman; Sulman, Tanti, and others.

28 van Baalen, de Groot, and Noordegraaf-
} Eelens; Roche and others; Trowsdale, McKenna, and Francis. 
them, since they must be completely independent in obtaining more comprehensive knowledge and they are forced to realized that knowledge is interrelated ${ }^{29}$. Thus, they are more like to create concepts and build a strong understanding of the material that can be used to deal with problems for a better quality future ${ }^{30}$. The STEAM approach in lectures is one way that can make a difference to student learning outcomes, and this can be seen from the data that researchers found in the field after the research process was carried out, whereby the experimental class using the STEAM approach had better learning outcomes in the cognitive domain.

The research process with the data that the researcher has obtained is in line with some studies which found that the STEAM approach can be an impetus for improvement in understanding knowledge in a manner that is more systematic, comprehensive, and structured $^{31}$. The STEAM approach can build the artistic spirit of students so that they can innovate in the field of biology education. This is important, especially due to the development of modern education today, which aims at maintaining student consistency in building quality education in the present and the future ${ }^{32}$. Innovation has now become a necessity for educational institutions in order to make a real contribution to the local community and the nation.

29 Merey Sarsengeldin and others, 'Interdisciplinary Connections and Their Influence on Mathematical Education of Students', Procedia - Social and Behavioral Sciences, 89 (2013), 866-71 <https://doi.org/10.1016/j.sbspro.2013.08.946>;

Nurfaradilla Mohamad Nasri and others, 'Uncovering Problems Faced by Science Teacher', Procedia - Social and Behavioral Sciences, 9 (2010), 670-73 $<$ https://doi.org/10.1016/j.sbspro.2010.12.215>.

30 de la Garza; Bertrand and Namukasa.

${ }^{31}$ Roche and others; van Baalen, de Groot, and Noordegraaf-Eelens; Trowsdale, McKenna, and Francis; de la Garza.

${ }^{32}$ Chen, Tang, and Mou; van Baalen, de Groot, and Noordegraaf-Eelens.
The Significance of the STEAM Approach in the Experimental Class on Student Learning Outcomes in the Cognitive Domain.

According to the data provided, the STEAM approach in online lectures significantly improves educational innovation learning outcomes ${ }^{33}$. The significant influence given by the STEAM approach is shown in the fact that during the lecture process carried out in the experimental class, students are always required to innovate to bring out their creativity in finding solutions and problems in the world of education ${ }^{34}$. The treatment process carried out using the STEAM approach provides a trigger in the student's personality to always think critically. ${ }^{35}$ In line with the findings that this study has described, other researchers also conclude that the STEAM approach can make a major contribution to the learning process, especially in improving the quality and abilities of students according to current demands. However, both can reinforce each other so that students' understanding of concepts becomes optimal as the result of the knowledge that is completely understandable from the point of view of mastery of learning outcomes that is truly complete. This understanding goes beyond the ability to apply an analysis of events. Rather it requires

33 Bertrand and Namukasa; Chen, Tang, and Mou; Cheng Tiao Hsieh, 'Developing Programmable Robot for K12 STEAM Education', IOP Conference Series: Materials Science and Engineering, 1113.1 (2021), $012008<$ https://doi.org/10.1088/1757$899 x / 1113 / 1 / 012008>$.

34 van Baalen, de Groot, and NoordegraafEelens; Bertrand and Namukasa; de la Garza.

35 Annelise Norlyk and others, 'Understanding the Creative Processes of Phenomenological Research: The Life Philosophy of Løgstrup', International Journal of Qualitative Studies on Health and Well-Being, 6.4 (2011) $<$ https://doi.org/10.3402/qhw.v6i4.7320>; Eva Bojner Horwitz and others, 'Arts as an Ecological Method to Enhance Quality of Work Experience of Healthcare Staff: A Phenomenological-Hermeneutic Study', International Journal of Qualitative Studies on Health and WellBeing, $\quad 12.1 \quad$ (2017) <https://doi.org/10.1080/17482631.2017.1333898>. 
creativity and innovation to solve real problems both conceptually and applying them ${ }^{36}{ }^{37}$. Thus, the students can become the best students of their time and can compete in global challenges in the future.

This research also carried out in-depth interview techniques for students in the experimental and control classes. The interview was carried out after the final test, namely the cognitive aspect test. The interview only focused on the process during which educational innovation lectures were carried out. In the experimental class, general information was obtained that students feel happy with the STEAM approach. They try to collect information that will be used in providing a creative and artistic solution to the problems presented. Hence, they always do the analysis first. This conforms to the student's desire to enact innovations that are exciting and not dull ${ }^{38}$. This leands to enthusiasm in the form of creativity and good artwork in providing biology learning solutions, so that these becomes an appropriate alternative during distance lectures and can increase student interest ${ }^{39}$.

The results of the lecture interviews showed that the occurrence of an ineffective online lecture process sometimes felt a little boring. Lectures in the control class of material presentation style are almost similar to the lecture method. The lecture process in the control class does not trigger the ability to innovate in the learning process. The ability to innovate in the form of creativity is not optimized, which results in the low willingness of students to understand the material being taught and not being enthusiastic about providing modifications in online lectures, in other words providing solutions to serious biology education problems, especially in biology learning innovation courses. The

36 Rozal and others.

$37 \mathrm{Zb}$, Setiawan, and others.

38 de la Garza; van Baalen, de Groot, and Noordegraaf-Eelens.

${ }^{39} \mathrm{Zb}$, Novalian, and others; Zb, Setiawan, and Sulman. research process that has been carried out shows that the control class also requires the right approach in the online lecture process as in the experimental class. The STEAM approach can be efficient and one of the right solutions to encourage students to be more creative and create more innovation. It has artistic value and is effective in learning biology, which can indirectly affect student learning outcomes in the cognitive domain more optimally.

\section{Conclusion}

Some facts have been obtained as a result of the research. According to the t-test analysis, there are differences in learning outcomes, with students in the experimental class using the STEAM approach having better learning outcomes in the cognitive domain than students in the control class. The researchers also conducted a phi correlation analysis, concluding that the STEAM approach in the experimental class had a significant impact on learning outcomes, particularly in the cognitive domain of students in the biology learning innovation. This research process is more focused on innovation and art in STEAM.

It is suggested that future researchers study STEAM in greater depth, including integrating a religious component, so that students are strengthened by innovating, thinking critically, having high artistic values, and better understanding themselves as God's creatures with advantages and disadvantages and who must constantly learn and improve themselves. The research process is expected to be the best reference and solution in distance and face-to-face lectures, particularly in biology learning innovation and biology education in general.

In this study, the researchers continue to use the STEAM approach in general, with the hope that other researchers who are interested in this research will be able to prepare, understand, and follow the STEAM approach process. The resulting research will demonstrate how the STEAM approach can be used at work and can have a broader impact on learning outcomes, allowing all 
STEAM activities to be examined in greater depth.

\section{References}

\section{Book}

Tatus, S, P Rospects, A N A Genda, and F O R R Esearch, 'Stem I Ntegration in K-12 E Ducation', March, 2014

\section{Journal}

van Baalen, Wander M, Tamara de Groot, and Liesbeth Noordegraaf-Eelens, 'Higher Education, the Arts, and Transdisciplinarity: A Systematic Review of the Literature', Research in Education, 2021, $\quad 003452372110057$ $<$ https://doi.org/10.1177/00345237211 005799>

Bertrand, Marja G., and Immaculate K. Namukasa, 'STEAM Education: Student Learning and Transferable Skills', Journal of Research in Innovative Teaching \& Learning, $13.1 \quad$ (2020), 43-56 $<$ https://doi.org/10.1108/jrit-01-2020$0003>$

Chen, Wu, Xin Tang, and Ting Mou, 'Course Design and Teaching Practice in STEAM Education at Distance via an Interactive E-Learning Platform', Asian Association of Open Universities Journal, 14.2 (2019), 12233 <https://doi.org/10.1108/aaouj-072019-0027>

Guo, Pengyue, Nadira Saab, Lysanne S. Post, and Wilfried Admiraal, "A Review of Project-Based Learning in Higher Education: Student Outcomes and Measures', International Journal of Educational Research, 102.November 2019 (2020), 101586 <https://doi.org/10.1016/j.ijer.2020.101 $586>$

Hayes, David, 'Against Critical Thinking Pedagogy', Arts and Humanities in Higher Education, $14.4 \quad$ (2015), 318-28 $<$ https://doi.org/10.1177/14740222155 92248>

Horwitz, Eva Bojner, Christina Grape Viding, Elisabeth Rydwik, and Ephrat Huss, 'Arts as an Ecological Method to Enhance Quality of Work Experience of Healthcare Staff: A Phenomenological-
Hermeneutic Study', International Journal of Qualitative Studies on Health and Well-Being, 12.1

$<$ https://doi.org/10.1080/17482631.201 7.1333898>

Hsieh, Cheng Tiao, 'Developing Programmable Robot for K12 STEAM Education', IOP Conference Series: Materials Science and Engineering, 1113.1 (2021), 012008 <https://doi.org/10.1088/1757$899 \mathrm{x} / 1113 / 1 / 012008>$

Kuzmickaja, Ilona, Xiaofeng Wang, Daniel Graziotin, Gabriella Dodero, and Pekka Abrahamsson, 'In Need of Creative Mobile Service Ideas? Forget Adults and Ask Young Children', SAGE Open, 5.3 (2015) <https://doi.org/10.1177/21582440156 01719>

de la Garza, Armida, 'Internationalizing the Curriculum for STEAM (STEM + Arts and Humanities): From Intercultural Competence to Cultural Humility', Journal of Studies in International Education, 25.2 (2021),

$123-35$ <https://doi.org/10.1177/10283153198 88468>

Meiliani, Meiliani, Tanti Tanti, and Fauzan Sulman, 'STUDENT RESOURCE ON NEWTON ' S LAW CONCEPTS REVIEWING FROM GENDER : IDENTIFICATION USING OPENENDED QUESTIONS', Indonesia Journal of Science and Mathematics Education, 04.November (2021), 324-32 $<$ https://doi.org/10.24042/ijsme.v4i3.10 $177>$

Nasri, Nurfaradilla Mohamad, Zakiah Mohd Yusof, Shanti Ramasamy, and Lilia Halim, 'Uncovering Problems Faced by Science Teacher', Procedia - Social and Behavioral Sciences, 9 (2010), 670-73 <https://doi.org/10.1016/j.sbspro.2010. $12.215>$

Norlyk, Annelise, Pia Dreyer, Anita Haahr, and Bente Martinsen, 'Understanding the Creative Processes of Phenomenological Research: The Life Philosophy of Løgstrup', International Journal of Qualitative Studies on Health and Well-Being, 6.4 (2011) <https://doi.org/10.3402/qhw.v6i4.732 
$0>$

Ozkazanc, Seher, and Ulku Duman Yuksel, 'Evaluation of Disaster Awareness and Sensitivity Level of Higher Education Students', Procedia - Social and Behavioral Sciences, 197.February (2015), 745-53 $<$ https://doi.org/10.1016/j.sbspro.2015. $07.168>$

Putra, M Ikhbal Jaya, M Junaid, and Fauzan Sulman, 'The Ability of the Question and Answer (Q\&A) Method with the Help of Learning Videos against Student Learning Outcomes amid the Covid-19 Pandemic', EDUKATIF: Jurnal Ilmu Pendidikan, 3.5 (2021), 2160-69 <https://doi.org/https://doi.org/10.310 04/edukatif.v3i5.768>

Roche, Joseph, Laura Bell, Ian Martin, Fiona Mc Loone, Amanda Mathieson, and Frida Sommer, 'Science Communication Through STEAM: Professional Development and Flipped Classrooms in the Digital Age', Science Communication, 2021 <https://doi.org/10.1177/10755470211 038506>

Rozal, Edi, Rizki Ananda, Aminah Zb, and Mohammad Fauziddin, 'The Effect of Project-Based Learning through YouTube Presentations on English Learning Outcomes in Physics', $A L$ ISHLAH: Jurnal Pendidikan, 13.3 (2021), 1924-33

$<$ https://doi.org/10.35445/alishlah.v13i $3.1241>$

Sarsengeldin, Merey, Askar Satabaldiyev, Zhaparov Meirambek, and Selim Guvercin, 'Interdisciplinary Connections and Their Influence on Mathematical Education of Students', Procedia - Social and Behavioral Sciences, 89 (2013), 866-71 $<$ https://doi.org/10.1016/j.sbspro.2013. 08.946>

Sremcev, Nemanja, Milovan Lazarevic, Branislava Krainovic, Jovan Mandic, and Milovan Medojevic, 'Improving Teaching and Learning Process by Applying Lean Thinking', Procedia Manufacturing, 17 (2018), 595-602 <https://doi.org/10.1016/j.promfg.2018 $.10 .101>$
Sulman, Fauzan, 'Application of Cooperative Problem Posing and Prior Motivation Towards Students Learning Outcomes', Indonesian Journal of Educational Research (IJER), $4.2 \quad$ (2019), 93-96 $<$ https://doi.org/10.30631/ijer.v4i2.126 $>$

Sulman, Fauzan, Sutop Sutopo, and Sentot Kusairi, 'FMCE-PHQ-9 Assessment with Rasch Model in Detecting Concept Understanding , Cheating , and Depression amid the Covid-19 Pandemic', Tadris: Jurnal Keguruan Dan Ilmu Tarbiyah, 6.2 (2021), 297-309 $<$ https://doi.org/10.24042/tadris.v6i2.9 273>

Sulman, Fauzan, Tanti; Tanti, Mhmd Habibi, and Aminah $\mathrm{Zb}$, 'Pengaruh Media Animasi Berkarakter Islami Terhadap Hasil Belajar Pengetahuan Bumi Dan Antariksa', Edumaspul: Jurnal Pendidikan, $5.1 \quad$ (2021), 135-46 $<$ https://doi.org/10.33487/edumaspul.v 5i1.1044>

Sulman, Fauzan, Muhammad Reyza Arif Taqwa, Aminah Zb Aminah Zb, Rafzan Rafzan, and Ahmad Fikri, 'The Effect of Mathematical Connections on the Mastery of Probability Material', Edumatika: Jurnal Riset Pendidikan Matematika, $3.2 \quad$ (2020), 147-57 $<$ https://doi.org/10.32939/ejrpm.v3i2.6 $45>$

Tatus, S, P Rospects, A N A Genda, and F O R R Esearch, 'Stem I Ntegration in K-12 E Ducation', March, 2014

Trowsdale, Jo, Ursula McKenna, and Leslie J. Francis, 'Teacher Evaluation of the Impact of The Imagineerium Education Project on the Creativity of Individual Students: The Trowsdale Index of Teacher Observation of Student Creativity', Research in Education, 2021 $<$ https://doi.org/10.1177/00345237211 014559>

Trueman, Rebecca J., 'Productive Failure in Stem Education', Journal of Educational Technology Systems, 42.3 (2014), 199-214 <https://doi.org/10.2190/et.42.3.b>

Tuan Soh, Tuan Mastura, Nurazidawati Mohamad Arsada, and Kamisah Osman, 
'The Relationship of 21 st Century Skills on Students' Attitude and Perception towards Physics', Procedia - Social and Behavioral Sciences, 7.C (2010), 546-54 <https://doi.org/10.1016/j.sbspro.2010. 10.073>

Zb, Aminah, Devie Novalian, Edi Rozal, Fauzan Sulman, and Mhmd Habibi, 'STEM Approach in Online Lectures: How Does It Contribute to Cognitive Aspects?', Indonesian Journal of Science and Education, $5.2 \quad$ (2021), $\quad 88-97$ $<$ https://doi.org/10.31002/ijose.v5i2.43 65>
Zb, Aminah, M. Eval Setiawan, Edi Rozal, and Fauzan Sulman, 'Investigating Hybrid Learning Strategies: Does It Affect Creativity?', Jurnal Kependidikan: Jurnal Hasil Penelitian Dan Kajian Kepustakaan Di Bidang Pendidikan, Pengajaran Dan Pembelajaran, $7.4 \quad$ (2021), $\quad 868-75$ <https://doi.org/10.33394/jk.v7i4.4063 $>$

Zb, Aminah, M Eval Setiawan, and Fauzan Sulman, 'Pengaruh E-Learning Berbasis Schoology Berbantuan WhatsApp Group Terhadap Hasil Belajar Ditengah Pandemi Covid-19', Al-Khidmah, 3.2 (2020), $55-60$ <https://doi.org/10.29406/alkhidmah.v3i2.2282> 